\title{
MENGAJAR DENGAN METODE MOTIMORFOSIS
}

\author{
Angga Rovita, Syarifah Ida Farida, Surasni, Teguh Yuwono, Achmad Sumali \\ Program Studi Manajemen \\ Universitas Pamulang \\ Email :dosen01667@unpam.ac.id
}

\begin{abstract}
The aim of community service is to provide training to participants to develop teaching using the motimorfosis method at 83 state junior high school Jakarta.The method used there are several stages including the preparation phase, which includes initial surveys, stabilization and determination of locations and targets. After the survey, the location of the implementation and target of the activity participants are determined. The next stage is the implementation phase of Community Service. This stage will be given understanding, knowledge and develop teaching with the motimorfosis method. This session focuses on providing an explanation of how the teacher can develop the motimorfosis method. And the last is the training stage, with several methods including lectures, questions and answers and simulations. The results of Community Service are that the participants (teachers) understand and understand more and gain knowledge about the latest teaching methods. There are several strategies that can be tried to develop the motimorfosis method, namely: 1) Motivation, 2) delagation, and 3) Appreciation. So the teacher does not create products but creates influence.
\end{abstract}

Keywords: Motimorfosis

\section{Abstrak}

Tujuan pengabdian kepada masyarakat ini untuk memberikan pelatihan kepada para peserta mengembangkan mengajar dengan metode motimorfosis di SMP negeri 83 jakarta.Metode yang digunakan ada beberapa tahap diantaranya tahap persiapan, yang meliputi survey awal, pemantapan dan penentuan lokasi dan sasaran. Setelah survey maka ditentukan lokasi pelaksanaan dan sasaran peserta kegiatan. Tahap berikutnya yaitu tahap pelaksanaan Pengabdian Kepada Masyarakat. Tahap ini akan diberikan pemahaman, pengetahuan dan mengembangkan mengajar dengan metode motimorfosis. Sesi ini menitik beratkan pada pemberian penjelasan mengenai bagaimana guru dapat mengembangkan metode motimorfosis. Dan yang terakhir merupakan tahap pelatihan, 
dengan beberapa metode diantaranya ceramah, tanya jawab dan simulasi. Hasil dari Pengabdian Kepada Masyarakat yaitu para peserta (guru) lebih mengerti dan memahami serta mendapatkan ilmu mengenai metode pengajaran yang terbaru. Ada beberapa strategi yang bisa dicoba untuk mengembangkan metode motimorfosis yaitu : 1) Motivasi, 2) delagasi, dan 3) Apresiasi. Sehingga guru tidak menciptakan produk namun menciptkan pengaruh.

Kata Kunci: Motimorfosis

\section{A. PENDAHULUAN}

Sekolah adalah Lembaga yang menjadi wada dalam belajar dan mengajar dalam pemberian ilmu pada siswa oleh guru. Tujuan adanya Lembaga tersebut agar terbentuknya harapan besar pada setiap generasi penerus sehingga mendapatkan mada depan yang baik untuk diri siswa dan bangsa Indonesia.

Mencapai prestasi belajar perlu adanya motivasi dari siswa baik eksternal maupun internal. Berdasarkan hasil observasi di salah satu sekolah masih banyak siswa tidak terlalu memperhatikan ketika penyampaian materi berlangsung setelah dilakukan wawancara dan beberapa di antara mereka mengatakan bahwa cara penyampaian guru yang membosankan dan terlalu menggurui, sehingga membuat mereka diperlakukan selayaknya anak kecil.

Sedangkan kurikulum yang digunakan adalah kurikulum 2013 Abad Milenial hal tersebut berbalik dengan isi kurikulum yang dilaksanakan, di mana siswa dituntut kecakapan dan keterampilan, yaitu berpikir kritis, komunikasi, kolaborasi, dan kreatif. Oleh karena itu guru perlu memahami bagaimana cara mengajar yang sesuai dengan kebutuhan Zaman dimana bisa dikatakan dengan guru abad 21.Guru Abad ke-21 harus mempunyai sejumlah karakteristik yang tepat untuk mengajar siswa milenial. Karakteristik tersebut antara lain menjadikan siswa sebagai producer, belajar teknologi baru, berwawasan global, siap dengan era digital, berkolaborasi, pembelajaran berbasis proyek, dan terus berinovasi.

Selain hal tersebut Setidaknya guru harus memiliki beberapa kompetensi meliputi: (1) kompetensi mendidik/pembelajaran, (2) Competence for technological commercialization, (3) Competence in globalization, (4) Competence in future strategies, dan(5) Conselor competence. Serta Peraturan Mendikbud (Permendikbud) Nomor 4 Tahun 2018 tentang Penilaian Hasil Belajar oleh Satuan Pendidikan dan Penilaian Hasil Belajar oleh Pemerintah, ujian nasional (UN) yang diselenggarakan oleh pemerintah, dan ujian sekolah berstandar nasional (USBN) yang diselengarakan oleh satuan pendidikan terus menerus disempurnakan. Secara substantif peningkatan kualitas soal ujian, baik ujian nasional maupun ujian sekolah berstandar nasional, yaitu dengan cara memasukkan bertahap standar soal yang disebut High Order Thinking Skill (HOTS). Guru-guru harus dilatih untuk dapat membuat soal dengan standar HOTS dengan hasil ujian nasional tidak jauh berbeda pada Program for International Student Assessment(PISA) dan Trends in International Mathematics and Science Study (TIMSS).

Survei Program for International Student Assessment (PISA) tahun 2018 baru saja dirilis. Survei PISA ini merupakan rujukan dalam menilai kualitas pendidikan di dunia. Hasil 
laporan PISA 2018 ini baru saja dirilis pada Selasa (3/12/2019). Studi ini menilai 600.000 anak berusia 15 tahun dari 79 negara setiap tiga tahun sekali. Studi ini membandingkan kemampuan matematika, membaca, dan kinerja sains dari tiap anakUntuk kategori kemampuan membaca, Indonesia berada pada peringkat 6 dari bawah alias peringkat 74. Skor rata-rata Indonesia adalah 371 , berada di bawah Panama yang memiliki skor rata-rata 377.Lantas, untuk kategori matematika, Indonesia berada di peringkat 7 dari bawah (73) dengan skor rata-rata 379. Indonesia berada di atas Arab Saudi yang memiliki skor rata-rata 373. Kemudian untuk peringkat satu, masih diduduki China dengan skor rata-rata 591

Berdasarkan latar belakang masalah di atas, maka kami Dosen Universitas Pamulang dan Yayasan Sasmita Jaya berkerja sama dengan SM Negeri 83 Jakarta beserta karyawan dan mahasiswa akan mengadakan Pengabdian Kepada Masyarakat (PKM) untuk memberikan pelatihan kepada Guru SMP Negeri 83 Jakarta dengan judul "Mengajar Dengan Metode Motimorfosis".

\section{B. METODE PELAKSANAAN KEGIATAN}

Metode kegiatan ini berupa pemberian pelatihan kepada guru mengenai metode motimorfosis, Berikut ini adalah tahapan pelatihan yang dilakukan:

1. Tahap persiapan, Tahappersiapan yang dilakukanmeliputi:

a. Survey awal,

b. Pemantapan dan penentuan lokasi dan sasaran. Setelah survey maka ditentukan lokasi pelaksanaan dan sasaran peserta kegiatan.

2. Tahap Pelaksanaan Pengabdian Kepada Masyarakat

Tahap ini akan diberikan penjelasan mengenai apa itu metode motimorfosis. Sesi ini menitik beratkan pada pemberian penjelasan mengenai bagaimana penerapan teknik mengajar dengan metode motimorfosis.

3. TahapPelatihan

Untuk melaksanakan kegiatan tersebut digunakan beberapa metode pelatihan yaitu:

a. Metode ceramah

b. Metode tanya jawab

c. Metode simulasi

\section{HASIL DAN PEMBAHASAN}

Sebelum melaksanakan Pengabdian Kepada Masyarakat kami selaku Dosen Universitas Pamulang melakukan prasurvey kepada Guru-guru SMP N 83 Jakarta. Berdasarkan data dan informasi yang kami dapatkan bahwa SMP N 83 Jakarta masih banyak siswa tidak terlalu memperhatikan ketika penyampaian materi berlangsung di antaranya cara penyampaian guru yang membosankan dan terlalu menggurui, sehingga membuat mereka diperlakukan selayaknya anakkecil.

Hal ini menuntut guru-guru meningkatkan kompetensi dalam bidang metode mengajarnya. Oleh karena itu, kami Dosen Universitas Pamulang melakukan pertemuan dengan SMP Negeri 83 Jakarta untuk memberikan solusi terhadap permasalahan yang ada di SMP Negeri 83 Jakarta.Pada tahap ini antara Universitas Pamulang dengan SMP Negeri 83 Jakarta melakukan Forum Group Discussion (FGD) untuk mempersiapkan pelaksanaan 
Pengabdian Kepada Masyarakat (PKM) untuk tanggal 23 - 25 Desember 2019 di SMP Negeri 83 Jakarta.

Pelaksanaan Pengabdian Kepada Masyarakat SMP Negeri 83 Jakarta pada tanggal 23 25 Desember 2019, terlaksana atas kerjasama Universitas Pamulang dengan SMP Negeri 83 Jakarta. Kegiatan ini di ketua oleh Angga Rovita, M.Pd. dengan nara sumber Arif Surahman, S.E., M.S.M dan dibantu dosen UNPAM lainnya yaitu Teguh Yowono, SS., M.M., Syarifah Ida Farida, S.E., M.M, Achmad Sumali, M.Pd. dan Dr. Surasni, M.Pd.

Kegiatan PKM ini dihadiri oleh dewan guru SMP negeri 83 Jakarta yang ingin menambah kompetensinya dalam bidang pendidikan. Pelaksanaan ini sangat ditunggu-tunggu oleh para guru SMP Negeri 83 Jakarta yang ingin mengembangkan kompetesinya dalam metode mengajar di Revolusi Industri 4.0.

Sebelum memulai acara dibuka oleh MC yaitu Acmad Sumali, M.Pd., dan pembacaan ayat suci Al Quran dan doa oleh Teguh Yuwono, SS., M.M., kami juga dibantu oleh para mahasiswa dari program studi manajemen sebagai bagian registrasi, konsumsi, dokumentasi dan peraga dalam pelatihan.

Setelah itu kata sambutan dari Kepala sekolah SMP Negeri 83 Jakarta yaitu dan perwakilan dari Universitas Pamulang yaitu Ketua Pelaksana PKM yaitu Angga Rovita, M.Pd.. Dilanjutkan sesi foto dokumentasi dan pelaksanaan Pelatihan SDM.Untuk melaksanakan kegiatan tersebut digunakan beberapa metode pelatihan yaitu:

\section{Metode ceramah}

Metode yang digunakan dalam pelatihan SDM (guru) dimulai dengan memberikan ceramah atau presentasi dengan tema "Mengajar Dengan Metode Motimorfosisi", dengan nara sumber Arif Surahman, S.E., M.S.M yang dibantu oleh Dr. Surasni, M.Pd

\section{Metode Tanya jawab}

Setelah sesi ceramah sudah selesai, maka dilanjutkan dengan sesi tanya jawab. Alhamdulillah peserta sangat antusias untuk menanyakan mengenai mengajar dengan metode motimorfosis. Peserta yang bertanya kami berikan cendremata dari Universitas Pamulang dan sumbangsih dari dosen-dosen UNPAM.

\section{Metode simulasi}

Pelatihan ini juga diberikan metode simulasi, sehingga peserta langsung dapat mempraktekan apa yang sudah disampaikan. Apabila ada kendala maka langsung dibantu pada saat pelaksanaan PKM. Simulasi penting dilakukan untuk mengetahui seberapa besar tingkat pengetahuan dan ilmu yang diserap pada saat pelatihan.

\section{KESIMPULAN DAN SARAN}

\section{Simpulan}

Pelaksanaan kegiatan Pengabdian Kepada Masyarakat oleh Lembaga Penelitian dan Pengabdian Masyarakat (LPPM) Universitas Pamulang yang dilakukan oleh dosen-dosen program studi Manajemen telah berjalan dengan lancar dan mendapat sambutan hangat dari tempat pelaksanaan kegiatan ini yaitu Kepala SMP N 83 Jakarta. Harapan kami dengan pengabdian ini dapat menambah ilmu yang bermanfaat dalam Mengembangkan metode pengajaran dengan motimorfosis. Dalam laporan kegiatan ini mungkin banyak kekurangan yang ada, untuk itu kami berharap masukan dan kritikan dalam rangka perbaikan untuk kegiatan-kegiatan pengabdian masyarakat dimasa yang akan datang. Semoga kegiatan 
pengabdian masyarakat ini dapat bermanfaat bagi masyarakat sekitar lingkungan Universitas Pamulang dan lainnya. Akhirnya, kami mengucapkan terimakasih kepada seluruh pihak yang telah mendukung kegiatan yang kami laksanakan dan kami mohon maaf apabila dalam laporan ini banyak ditemukan kekurangan.

\section{Saran}

1. Guru SMP Negeri 8 jakarta diberikan pendampingan dalam mengembangkan metode pengajaran.

2. Adanya kontribusi dari pihak universitas untuk bisa memberikan fasilitas dalam pelayanan kepada masyarakat dalam bentuk sarana dan prasarana.

\section{DAFTAR PUSTAKA}

Christensen, C. M. (1997). The Innovator's Dilemma. harvard: Harvard Business. 2

Krulik, S., \& Rudnick, J. A. (1999). Innovative Tasks to Improve Critical and Creative Thinking Skills. Developing Mathematical reasoning in Grades K-12, 138-145

Kurniati, D. (2016). Kemampuan Berpikir Tingkat Tinggi Siswa SMP Di Kabupaten Jember Dalam Menyelesaikan Soal Berstandar PISA. Penelitian dan Evaluasi Pendidikan 20(2), 142-155. Jurnal.id. (2015, Maret 12). Retrieved from https: // media. neliti. Com /media/publications/22939-ID-analisis-kompetensi-profesional-guru-ditaman-kanak-

kanak-kecamatan-kampar-provi.pdf OECD, PISA. 2017. How Does PISA for Development measure mathematical literacy. Paris: OECD Publisher.

Peraturan Menteri pendidikan nasional Republik Indonesia Nomor 16 tahun 2007 tentang standar kualifikasi akademik dan kompetensi guru

Saputra, H. (2016). Pengembangan Mutu Pendidikan Menuju Era Global: Penguatan Mutu Pembelajaran dengan Penerapan HOTS (High Order Thinking Skills). Bandung: SMILE's Publishing

Setiawan, H. D., \& Diah, N. (2014). Soal Matematika dalam PISA Kaitannya dengan Literasi Matematika dan Keterampilan Berpikir Tingkat Tinggi. In Prosiding Seminar Nasional Matematika. Jember

Undang-Undang No.20 Tahun 2003 tentang Sistem Pendidikan Nasional. Jakarta: Depdiknas. 